\title{
A memória na luta contra o trauma: significados da greve de Osasco em 1968 nas narrativas de trabalhadores
}

\author{
Marta Gouveia de Oliveira Rovai*
}

Resumo: Este artigo analisa um conjunto de narrativas orais de metalúrgicos que participaram da histórica greve de Osasco no ano de 1968. Com o processo de redemocratização, iniciado na década de 1980, depois do longo "silenciamento" produzido pelo regime autoritário, as memórias subterrâneas desses trabalhadores emergiram. Desde 1987, acompanhei a atuação dessa comunidade, profundamente marcada por perdas e traumas e também por projeções políticas e sociais que delineiam sua formação identitária. Particularmente, neste artigo, procurei tratar da luta contra os estereótipos negativos, o esquecimento, a memória e a história oficiais construídas pelo regime autoritário sobre a greve.

Palavras-chave: 1968; greve em Osasco; ditadura civil-militar; trabalhadores.

Abstract: This article analyses a set of oral narratives of workers who took part in the famous 1968 metalworkers strike in Osasco. In the 1980s, during the Brazilian redemocratization process, silences and repressed memories of these workers emerged. Since 1987, I have examined these traumatized remembrances, which are vital for a specific process of identity formation. In this article, I focus particularly in the workers struggle against the forgetfulness and the official authoritarian memory and history about the strike.

Keywords: 1968; metalworkers strike in Osasco; military dictatorship; workers.

\section{Introdução}

Durante a ditadura civil-militar a cidade de Osasco, localizada na Grande São Paulo, assistiu e sentiu a repressão contra uma greve que marcou de diferentes formas a vida de seus habitantes e principalmente dos trabalhadores nela envolvidos. No auge das manifestações contrárias ao regime instituído com o golpe de 1964, a paralisação foi organizada por operários das principais fábricas metalúrgicas do município, entre elas, Cobrasma, Braseixos e Cimaf, e ocorreu a partir de uma decisão coletiva de vários sindicatos, cabendo destaque ao de

* Professora adjunta de História na Universidade Federal de Alfenas (UNIFAL/MG), pesquisadora do Núcleo de Estudos em História Oral (NEHO/USP), do Núcleo de Pesquisa Cidade, Cultura e Identidade (CCI/UESPI) e do Grupo de Pesquisa História do Brasil: Memória, Cultura e Patrimônio, da UNIFAL. 
Contagem, em Minas Gerais. ${ }^{1}$ Um acordo entre eles deu origem ao Movimento Intersindical Antiarrocho (MIA), em 1967, prevendo o enfrentamento nacional ao arrocho salarial e ao regime, por meio de uma grande paralisação que aconteceria em outubro de 1968, época do dissídio coletivo da categoria.

Em meio a divergências políticas e estratégicas quanto ao MIA, os operários osasquenses decidiram antecipar o movimento para 16 de julho, animados pelos resultados - analisados por eles como favoráveis - da greve em Contagem, da articulação com o movimento estudantil e do enfrentamento com as forças do governo no manifesto de Primeiro de Maio, realizado na Praça da Sé, em São Paulo. Nesse dia, a fábrica da Cobrasma, onde se iniciou a paralisação, foi invadida durante a noite pela Força Nacional, enquanto a sede do Sindicato dos Metalúrgicos da cidade era cercada, permanecendo vigiada por alguns dias, numa caça aos grevistas. Apesar de o evento ter sido breve, pois durou apenas um dia, as influências políticas, os projetos, as frustrações e, principalmente, o impacto da repressão sobre os trabalhadores e suas famílias permaneceram na memória coletiva dessa comunidade afetiva ou de destino. ${ }^{2} \mathrm{O}$ contato durante anos com essas histórias, informalmente, por ser moradora da cidade, inspirou-me a realizar uma pesquisa de Doutorado, concluída no final de 2012, sobre a memória - ou as memórias - dessas experiências e seus significados para quem as viveu. ${ }^{3}$

Alguns trabalhos sobre a greve já haviam sido escritos até então, preocupados em analisar os fatos relacionados à construção política da greve e ao papel do sindicato. ${ }^{4}$ Apesar disso, notei um profundo silêncio e desconhecimento sobre este acontecimento entre os habitantes da cidade. Houve ali, durante anos, uma "memória interditada, proibida" que, como afirmou Michael Pollak, "longe de conduzir ao esquecimento, é a resistência que uma sociedade civil impotente opõe ao excesso de discursos oficiais". ${ }^{5}$ As memórias, individuais e coletivas, permaneceram como rios subterrâneos, no cotidiano dos operários e de suas famílias, continuamente tema de conversas informais, sob uma história oficial desqualificadora daqueles que foram perseguidos e presos, até o momento de emergirem no processo de transição democrática dos anos de 1980.

Nesse sentido, o objetivo de minha pesquisa foi oferecer escuta atenta a essas narrativas inconformadas, traumatizadas e ressentidas, ao mesmo tempo orgulhosas do movimento. Ao todo, foram realizadas 21 entrevistas, entre trabalhadores e suas famílias (principalmente suas mulheres e irmãs), cabendo destaque aqui à história oral de vida daqueles que estiveram diretamente ligados à condução da greve. ${ }^{6}$ Por se tratar de uma breve análise das memórias, não nomearei todos eles nem

1 Em Contagem aconteceu o primeiro grande movimento sindical do país, após o golpe de 1964, e serviu de exemplo aos outros trabalhadores, que decidiram fazer uma paralisação nacional. Os mineiros organizaram uma greve em empresas como Belgo Mineira e Mannesman, em abril de 1968, paralisando cerca de vinte mil operários. Apesar da repressão, eles conseguiram atingir sua principal reivindicação, que era o aumento salarial.

2 Segundo Maurice Halbwachs, a comunidade afetiva ou de destino seria aquela marcada pela mesma experiência coletiva e que manteria viva a memória sobre determinados fatos significativos ao grupo HALBWACHS, Maurice. A memória coletiva. São Paulo: Vértice, 2006.

3 A respeito da memória dos trabalhadores osasquenses sobre a greve ver: ROVAI, Marta Gouveia de Oliveira. Osasco 1968: a greve no masculino e no feminino. Salvador: Editora Pontocom, 2013, e-book, link http://www. editorapontocom.com.br/livro/19/19-marta-rovai-osasco-1968.pdf. Este artigo se baseia nesse trabalho.

4 Cabe destaque aos trabalhos de MIRANDA, Orlando. Obscuros heróis de capricórnio, São Paulo: Global, 1987; COUTO, Marcelo. Greve na Cobrasma: uma história de luta e resistência. São Paulo: Annablume, 2003.

5 POLLAK, Michael. Memória, esquecimento e silêncio. Estudos Históricos, Rio de Janeiro, vol. 2, n 3, p. 3-15, 1989.

6 Embora a tese tenha tratado das relações de gênero na memória coletiva, não abordarei esta temática aqui, pois a discussão em torno das lembranças e falas femininas e masculinas demandaria outro artigo, que analisaria outras "memórias subterrâneas" e extrapolaria o que o presente artigo se propõe. 
apresentarei trechos de seus relatos, mas tratarei da memória coletiva cindida em dois grupos representativos da liderança operária: o Grupo Osasco, assim nomeado por seus membros, ligado ao movimento estudantil e à luta armada, e a Frente Nacional do Trabalho (FNT), nascida das fortes relações com a Juventude Operária Católica (JOC) e as Comunidades Eclesiais de Base (CEBs). ${ }^{7}$

Não pretendi "dar voz" a eles - um entendimento por vezes pretensioso dos historiadores - mas ouvi-los, uma vez que a palavra a eles pertence, assim como a decisão de dizer. Seus relatos representaram testemunho político da organização do movimento grevista, da repressão promovida pelo regime autoritário e da resistência a ela, mas também revelaram a fé religiosa dos membros da Frente Nacional do Trabalho ou a crença política na revolução, por parte dos militantes do Grupo Osasco. Em comum, demonstraram o medo da tortura e da possibilidade do desaparecimento, os sonhos e a vontade de continuar lutando por formas mais democráticas e humanizadas de conviver. Escutá-los representou tocar em feridas abertas, numa experiência limite, extrapolando tempo cronológico e espaço, e colocar em discussão a política pública de reparações, em tempos de "Nunca Mais". ${ }^{8}$ O testemunho - sempre subjetivo - cumpre papel importante para a história, quanto ao compartilhamento e enfrentamento de um trauma histórico, coletivo e, muitas vezes, ainda subterrâneo, relacionado às dores e aos "silenciamentos" promovidos pelas violações e acusações que condenaram os operários e seus familiares a um tratamento desumano por meio da vigilância, da prisão e do exílio.

Ao tratar da memória, concordo com Alessandro Portelli quanto ao fato de as narrativas orais poderem nos ajudar a compreender não apenas os custos políticos da greve de Osasco, mas seu "preço psicológico e emocional” para a coletividade. ${ }^{9}$ Assim, não apenas lembrar o que aconteceu, mas mostrar o que pensam sobre o que poderia ter sido aquele momento e a projeção de novos horizontes para os trabalhadores são formas de se posicionarem dentro da história.

Nesse sentido, a partir de suas narrativas e da historiografia, apresento um pequeno histórico do processo de constituição da greve de Osasco em 1968, os consensos e divergências na memória coletiva dos entrevistados e a avaliação que fazem hoje de suas ações durante o período da ditadura civil-militar. Cabe lembrar que, tratando-se principalmente de memória, o olhar recaiu sobre os sentidos e a intersubjetividade dos narradores, sempre presentificados pelas trajetórias de vida de cada um em relação à comunidade afetiva..$^{10}$

7 O Grupo Osasco foi formado pelos operários osasquenses que participaram da Vanguarda Popular Revolucionária (VPR), chegando a 65 membros. Era liderado pelo capitão Carlos Lamarca, ex-integrante do Exército que tinha aderido à luta armada e liderava a VPR. Especificamente sobre o grupo ver também OLIVEIRA, Sérgio Luís S. O grupo (de esquerda) de Osasco. Movimento estudantil, sindicato e guerrilha (1966-1971). Dissertação (Mestrado, Faculdade de História), Universidade de São Paulo, São Paulo, 2011.

8 A expressão "Nunca Mais" se refere aqui aos diferentes movimentos na América Latina, inclusive no Brasil, de denúncia e rememoração das atrocidades cometidas pelas ditaduras, a fim de que sejam discutidas as responsabilizações e ações de justiça, para que novas práticas de violência não se repitam. Neste processo desenvolve-se a chamada justiça de transição, em que o Estado assume o papel de reparar os crimes cometidos contra os direitos humanos. As reparações podem se dar de diferentes formas: pela indenização, pela publicização dos nomes dos culpados, pelo acompanhamento psicológico ou pelo julgamento e criminalização dos violadores.

9 PORTELLI, Alessandro. O que faz a história oral diferente. Projeto História. São Paulo, n 14, 1996.

10 Luisa Passerini nomeou intersubjetividade a construção coletiva pela memória, quando silêncios, lembranças e esquecimentos individuais apresentam-se como parte do mesmo processo de alternância, de escoIhas feitas em conjunto, pela vivência social, principalmente com relação a traumas coletivos em regimes de força. PASSERINI, Luísa. Memoria y utopia: la primacia de La intersubjetividad. Valencia: Universitat de Valencia, 2006, p. 41. 


\section{Osasco: a cidade operária que construiu a greve de 1968}

O perfil de cidade operária de Osasco começou a se constituir desde o início do século XX, quando, em 1909, uma cooperativa foi formada por anarquistas que haviam participado de uma greve na vidraria Santa Marina, em São Paulo, e que se deslocaram para a região após a demissão coletiva e a doação de terras feita por um conterrâneo, um pequeno empresário de Osasco chamado Antônio Agu. ${ }^{11}$ No contexto de modernização industrial promovida pelos governos de Getúlio Vargas e Juscelino Kubitschek, entre os anos de 1940 e 1950, grande número de migrantes vindos do interior de São Paulo, do Nordeste e do Sul do país, foi atraído para trabalhar nas empresas que se instalavam no então bairro paulistano, ${ }^{12}$ dentre elas a Cobrasma (1944), a Cimaf (1946), a Lonaflex (1951) e a Braseixos (1959). Segundo Cibele Saliba Rizek, a quantidade de terrenos mais baratos e a proximidade com a ferrovia que foi construída, propiciando o escoamento de produtos e a circulação de pessoas, teria facilitado a chegada dessas fábricas na região. ${ }^{13}$

A década de 1960 foi marcada, também, por transformações que ampliaram o acesso desses trabalhadores ao Ensino Secundário, destacando-se a fundação do Colégio Estadual Antônio Raposo Tavares (Ceneart), onde se encontraram operários e filhos da elite local, formada por comerciantes e pequenos industriais. O curso noturno promoveu o aprendizado daqueles que Francisco Weffort nomeou como "operários-estudantes", que lidavam na fábrica durante o dia e à noite debatiam política. ${ }^{14}$ Foram eles os criadores de grupos de teatro nas escolas e nas fábricas, de um jornal estudantil chamado Bacamarte, assim como dos primeiros grêmios e órgãos estudantis na cidade, além de uma chapa sindical que venceu as eleições de 1967, no Sindicato dos Metalúrgicos, com membros operários e estudantes.

Em 1962 já era possível observar o início de um processo de politização que se intensificou após o golpe de 1964, com a circulação constante de intelectuais da Universidade de São Paulo (USP) e de membros dos ainda incipientes grupos armados nos sindicatos, nas escolas e nas casas dos trabalhadores, processo que culminou com a greve de $1968 .{ }^{15}$ Esse ano foi significativo, pois foi quando alguns eventos sinalizaram diferentes tensões e interesses na sociedade osasquense: a fundação da Frente Nacional do Trabalho (FNT), ligada aos círculos operários e guiada pelos Princípios para a Ação, do padre francês Lebret; e a criação da comissão de fábrica na Cobrasma, a partir da morte de um operário na caldeira.

A Frente Nacional do Trabalho nasceu das Comunidades Eclesiais de Base, que atuavam nos bairros mais pobres, em todo o Brasil, fortemente influenciadas pelas orientações do papa João XIII durante o Concílio Vaticano II (1962-65). Inspiradas por um ideário de aliança com a população das periferias em busca de uma Igreja mais humanizada e cujas ações se embasariam no preceito "Ver, julgar e agir",

11 Sobre a greve dos vidreiros e a formação da cooperativa de caráter anarquista ver: WERNER, Helena Pignatari. Raízes do movimento operário em Osasco. Petrópolis: Vozes, 1981.

12 Osasco conseguiu sua emancipação como cidade em 1962, após três plebiscitos.

13 RIZEK, Saliba. Osasco 1968: a experiência de um movimento. Dissertação (Mestrado), Faculdade de História, PUC, São Paulo, 1988.

14 WEFFORT, Francisco. Participação e conflito social: Contagem e Osasco: 1968. Cadernos CEBRAP, n 5, São Paulo, 1972.

15 Foram constantes nas narrativas as referências aos membros de agrupamentos políticos que vinham arregimentar operários para os movimentos de enfrentamento à ditadura, depois do golpe, principalmente o grupo conhecido como O. e, mais tarde, a Vanguarda Popular Revolucionária (VPR). 
as CEBs atraíram muitos operários. Em Osasco, muitos padres, principalmente de origem francesa, como Pierre Wauthier e Domingos Barbè, decidiram empregarse nas fábricas, procurando vivenciar as adversidades sofridas no cotidiano. Eles também colaboraram na organização da greve e posteriormente foram presos e expulsos do país. Operários, como João Joaquim, Inácio Gurgel, João Cândido e José Groff, com quem tive a oportunidade de dialogar, ingressaram na FNT procurando mediar os valores da Igreja considerada mais progressista com o que chamaram de "luta pela base" no espaço de trabalho.

No mesmo processo de politização, os operários-estudantes, como Roque Aparecido da Silva, Antônio Roberto Espinosa, José Ibrahin e José Campos Barreto ${ }^{16}$ integravam-se às manifestações de caráter nacional, participando da União Nacional dos Estudantes e criando o Círculo Estudantil de Osasco (CEO), assim como a União dos Estudantes de Osasco (UEO) cujas bandeiras eram a ampliação de vagas nas universidades públicas, a denúncia da corrupção de vereadores, o debate sobre os direitos trabalhistas e sobre o cenário revolucionário que se ampliava mundialmente. As revoluções cubana e chinesa, assim como as ideias de Mao Tse Tung e Che Guevara, inspirariam, mais tarde, a formação do Grupo Osasco, ligado à VPR.

O golpe civil-militar de 1964 atingiu duramente o processo de mobilização no país e na cidade de Osasco. No entanto, em 1965, os operários-estudantes continuavam a realizar reuniões de caráter clandestino, debates nas fábricas e escolas, além de festivais de música, procurando resistir aos desmandos do regime autoritário. O Círculo Estudantil de Osasco, juntamente com os trabalhadores, obteve uma conquista importante: o direito de terem representantes em gabinetes da Prefeitura nas eleições de 1966 como condição para apoiar um candidato do MDB, considerado por eles mais moderado. ${ }^{17}$

No ano de 1967, operários e operários-estudantes da fábrica Cobrasma formaram uma chapa para concorrer às eleições para o Sindicato dos Metalúrgicos de Osasco, que estava sob intervenção do Estado desde 1964. Apesar da presença do interventor, houve permissão para que a diretoria do Sindicato fosse renovada pelos jovens que, aparentemente, acreditava-se não representar "perigo político". ${ }^{18}$ Aqueles que mantinham contato com grupos guerrilheiros e os representantes da Frente Nacional do Trabalho conseguiram compor a Chapa Verde, numa congregação de crenças políticas diferentes para fazer frente ao governo e ao Partido Comunista $(P C B)$, que até então tinha poder hegemônico na diretoria do Sindicato e que era considerado pela chapa de oposição como demasiadamente submisso ao regime.

A FNT entendia que a organização trabalhista deveria começar pela base, dentro das fábricas, como era a orientação das Comunidades Eclesiais de Base e da Juventude Operária Católica (JOC). Os estudantes, influenciados pela esquerda armada, acreditavam que uma greve poderia servir para articular intelectuais e

16 José Campos Barreto, chamado pelos narradores de Barretão ou Zequinha, era operário e estudante de Ciências Sociais na Universidade de São Paulo. Foi também militante da VPR, tendo sido assassinado junto com o capitão Carlos Lamarca, líder da organização, numa emboscada do exército em 1971, na Bahia. Inácio Gurgel e José Ibrahin faleceram recentemente, em 2011 e 2013, respectivamente.

17 Guaçu Piteri, segundo prefeito da cidade, era ligado ao MDB e governou entre 1967 e 1970, sendo conhecido por sua postura conciliadora. De seu governo participaram Roque Aparecido da Silva, escolhido pelos estudantes, e José Ferreira Batista, eleito pelo movimento sindical. Foi Piteri quem doou também o prédio para que o Círculo Estudantil de Osasco (CEO) se organizasse.

18 Segundo os entrevistados, o fato de serem muito jovens - com cerca de 20 anos - e serem desconhecidos politicamente pelo governo, deu a eles certa vantagem para agir nas fábricas e no Sindicato até o dia da greve. 
trabalhadores na luta contra a ditadura. O nascimento do Movimento Intersindical Antiarrocho (MIA) e a vitória da Chapa Verde nas eleições, em 1967, deram aos trabalhadores a certeza do fortalecimento na luta contra o arrocho salarial instituído pelo governo do presidente Marechal Castelo Branco. Sobre isso, as narrativas dos entrevistados demonstraram sentimentos de conciliação e consenso, na tentativa de que "cristãos anticomunistas, mas humanistas" e "uma esquerda renovada" pela juventude pudessem se unir contra inimigos em comum: o capital e a ditadura civil-militar. ${ }^{19}$

Marcelo Ridenti chamou Osasco de "Meca da esquerda brasileira" naquele momento, enxergando nos movimentos sindicais e políticos da cidade, assim como em Contagem, a manifestação do "romantismo revolucionário". ${ }^{20}$ Mais do que espelho dos acontecimentos internacionais contra o Imperialismo e o conservadorismo, e da luta pela democracia, para ele germinava ali uma forte utopia de mudança, desejo de renovação, contra a pobreza e as relações injustas no trabalho, convergindo forças políticas das mais diferentes configurações e lugares. ${ }^{21}$

Mesmo que essas ideias não tenham sido hegemônicas, pois diferentes conceitos, sentimentos, ações e desejos continuaram a existir - o que Ridenti chamou de "zonas cinzentas" - elas se tornaram fortes referências ao movimento osasquense. Havia a crença de que mudanças radicais poderiam e estavam por acontecer a partir das intervenções promovidas por intelectuais, trabalhadores e estudantes. Era um momento em que se apostava na possibilidade de alteração de valores e no potencial criativo da coletividade.

Segundo os membros do Grupo Osasco, a participação em manifestações contra o regime e a organização de uma passeata em Osasco - simultaneamente a outras que aconteciam pelo país em protesto contra o assassinato do secundarista Edson Luís, no Rio de Janeiro, em 28 de março de 1968 - fortaleceram neles a vontade de enfrentamento com o governo e a utopia da vitória sobre ele. Para os membros da FNT, embora não tivessem feito parte dos protestos, a leitura religiosa e política sobre os movimentos, naquele instante, lhes deu a certeza de que uma Igreja humanizada, em sintonia com os trabalhadores, facilitaria acordos, sem o uso da violência. Esse conjunto de experiências acumuladas pelos operáriosestudantes e metalúrgicos católicos de Osasco levou-os a acreditar que a greve poderia ser antecipada para o mês de julho, pois haveria um contexto favorável à resistência sindical.

\section{O significado do Primeiro de Maio na memória coletiva}

Quando os membros do Grupo Osasco e da FNT lembraram os acontecimentos que precederam a greve de julho de 1968, pode-se notar um processo constante

19 No entanto, a tensão em torno da autoria da comissão de fábrica e da liderança da Chapa Verde, entre a FNT e o Grupo de Osasco ainda permaneceu nas narrativas de seus participantes, cada qual chamando para seu grupo a ideia e a origem.

20 RIDENTI, Marcelo; ANTUNES, Ricardo. Operários e estudantes contra a ditadura: 1968 no Brasil. Mediações, vol. 12, n², p. 78-89, 2007.

21 Ridenti trabalhou com o conceito de Michael Lowy, citado em seu artigo intitulado Intelectuais e romantismo revolucionário. São Paulo em Perspectiva, vol. 15, n², São Paulo, 2001. 
de negociação e posicionamento na memória coletiva. As narrativas revelaram momentos ora de tensão, ora de consenso, procurando manter sentimentos de pertencimento à comunidade afetiva, reconhecimento de uma luta em conjunto, mas também marcações no território político.

Se para os estudantes-operários, o papel das entidades estudantis e grupos armados foi fundamental para pensar e colocar em prática a greve, para os participantes da FNT não haveria qualquer relação entre suas ações e instituições ou ideologias político-partidárias. Pelo contrário, para eles a opção pela paralisação em 1968 teria sido fruto de um apostolado religioso pacifista mais voltado ao povo. Movidos pela filosofia cristã de "ser firme o tempo todo, e não valente de vez em quando" opuseram-se ao caráter revolucionário das propostas de seus companheiros socialistas. Colocaram-se como defensores da negociação com o "adversário", o patrão capitalista, que deveria ser seduzido pelo ideal católico de conciliação e não pelo "enfrentamento radical oportunista".

As diferenciações, no entanto, não impediram que as memórias individuais reconhecessem "os diferentes", o "outro lado", enquanto militantes de formas também válidas de luta. Referências a eventos fundadores da causa em comum entre eles fizeramparte do que chameide "pacto narrativo" entreos trabalhadores. Entendo, como sugere Michael Pollak, que como a memória é um fenômeno construído, existem fatos, lugares e personagens que são apresentados como vestígios compartilhados pelo grupo..$^{22}$ Essas referências reforçaram a identidade coletiva e ajudaram a construir a imagem de como a coletividade pretende ser reconhecida e significada no presente. No caso das duas redes de narradores aqui citadas, alguns "acontecimentos vividos pessoalmente" e aqueles "vividos por tabela", como o nascimento da comissão de fábrica e a vitória da Chapa Verde, tornaram-se marcos cronológicos e simbólicos do enfrentamento da própria ditadura, na década de 60. No lugar de memória herdada, como nomeou Pollak, diria que são fatos partilhados e filtrados pela experiência da coletividade, uma vez que as lembranças não podem ser coisificadas e continuam a ser alimentadas enquanto significam.

A memória coletiva pode ser entendida como construção submetida a flutuações, transformações e divergências que não alteram determinados marcos identitários. Mesmo que as falas tenham sido orientadas pelas experiências individuais e pelas diferentes concepções políticas, alguns elementos, eventos e períodos permaneceram centrais nas histórias contadas conjuntamente. Em certo sentido, revolucionários e cristãos foram unânimes em apontar a experiência coletiva da greve como inovadora, assim como suas ações, seja pela via religiosa ou pela militância mais política, como importantes para a mudança em suas vidas pessoais e também para o amadurecimento da militância dos sindicatos brasileiros. Os relatos sobre a participação no evento do Primeiro de Maio, realizado na Praça da Sé, em 1968, por exemplo, destacaram um dos aspectos que compuseram esse fio condutor afetivo da memória, ao mesmo tempo coesa e múltipla.

A manifestação de Primeiro de Maio foi um desses momentos de comunhão, decisivo para que os operários decidissem pela greve em julho daquele ano. As palavras proferidas adquiriram força nas narrativas, como se cada momento vivido na Praça da Sé fosse um feito extraordinário, fruto da união das diferentes redes, com suas intenções, expectativas e sonhos. Cada qual, à sua maneira, deu

22 POLLAK, Michael. Memória e identidade social. Estudos Históricos, Rio de Janeiro, vol. 5, n 10, p. 200-212, 1992. 
brilho às ações coletivas, com falas emocionadas e vibrantes, num processo de presentificação de sentimentos passados. O testemunho se intensificava, pelo ritmo mais acelerado e empolgado da narrativa, ou pela pausa, expectativa para causar o riso desdenhoso, vitorioso, sobre seus perpetradores. $\mathrm{O}$ ato de contar, nesse sentido, não significou apenas dizer sobre o que vivenciaram, mas contagiar o ouvinte e partilhar com a comunidade de destino o grande feito coletivo.

A ênfase ao grande número de trabalhadores presentes ao evento revelou uma tentativa do grupo de impressionar: "oito mil", "dez mil”, "vinte mil", "cem mil pessoas"! Nesse dia, segundo os relatos, o governador de São Paulo, Abreu Sodré, teria comparecido ao protesto sem o consentimento deles e teria subido ao palanque para discursar. Revoltados com sua presença, os metalúrgicos o vaiaram e fizeram pressão para que ele se retirasse, até que uma pedra foi atirada em sua cabeça. Utilizando palavras de ordem contra a ditadura, muitos teriam tomado o palco, segurando paus e bandeiras, e ateado fogo aos materiais que ali havia. Este ato, lembrado por todos os entrevistados, foi considerado uma demonstração de força dos sindicatos e o preparo dos espíritos para a greve que aconteceria posteriormente.

Para os membros do Grupo Osasco, como Roque Aparecido, José Ibrahin e Antônio Roberto Espinosa, mais do que o confronto entre capital e trabalho, aquele evento significou estar sob o comando de guerrilheiros da VPR, que estariam postados no alto de prédios e prontos a agir, caso fosse necessário. Naquele momento, esses entrevistados já estavam em contato com a organização armada e, segundo eles, a manifestação na Praça da Sé não se restringia à questão trabalhista. Temendo a repressão pelo Exército aos vários grupos que chegavam de pontos diferentes do estado ao centro de São Paulo, parte dos operários se preparava para o confronto, tendo a cobertura dos militantes armados, ordenados pelo capitão Carlos Lamarca. Por estarem à frente da greve e envolvidos politicamente com a guerrilha, esses narradores tinham como referência de resistência os eventos internacionais, como a Revolução Cubana e a Chinesa, ou a própria Rússia, assim como modelos de liderança representados por Che Guevara, Lênin ou Mao Tse Tung. Essa inspiração fazia com que sua leitura sobre Osasco fosse revolucionária, referindo-se a ela como a "capital da resistência", a "Petrogrado brasileira", de onde poderia nascer o sonho socialista.

De outra forma, os participantes da FNT conduziram suas ações acreditando na ideia do sacrifício, representado não apenas por Jesus Cristo, mas também por Gandhi, símbolos da persistência não violenta. Para eles, não haveria vitória sem sofrimento, o que justificou, inclusive, a sua prisão e a tortura sofrida durante a perseguição pelo regime.

Seja do ponto de vista da Frente Nacional ou dos militantes ligados à guerrilha, o Primeiro de Maio foi decisivo para que "ditassem" a história, colocando-se como agentes de uma odisseia que parecia vitoriosa. Animados pela organização do MIA, pela vitória da Chapa Verde em Osasco e dos operários em Contagem, além da euforia pelo enfrentamento na Praça da Sé e por suas convicções políticas e/ ou religiosas, eles avaliaram o contexto como favorável para que pudessem se organizar contra os patrões e o autoritarismo, numa aliança necessária. 


\section{Memórias sobre opressão e resistência: a greve de Osasco}

A greve, iniciada na manhã do dia 16 de julho de 1968, tinha como estratégia a ocupação da Cobrasma pelos trabalhadores, expandindo-se para outras empresas, como a Braseixos, a Cimaf e a Santista. Os operários osasquenses acreditavam que a antecipação da paralisação, planejada pelo Movimento Intersindical Antiarrocho (MIA) para o final do ano, promoveria uma "onda" que atingiria fábricas no $A B C$ paulista e em Santos, fortalecendo o movimento sindical contra o arrocho salarial. Algumas interpretações de ações e acontecimentos, no entanto, divergem na memória coletiva quanto ao encaminhamento das negociações com os patrões, à participação de estudantes secundaristas e universitários e à violência por parte de alguns grevistas.

Passagem em comum na memória das duas redes de entrevistados foi o sequestro de engenheiros pelos metalúrgicos, aprisionados dentro da própria empresa, na tentativa operária de forçar a negociação com os donos da Cobrasma. Apesar do riso dos narradores, que acompanhou a maior parte das lembranças sobre esse fato, foi unânime a referência à tensão provocada por eles em relação à direção da fábrica e aos militares que cercavam as ruas ao redor. Além disso, Roque Aparecido da Silva e Antonio Roberto Espinosa se articulavam com a União Nacional dos Estudantes (UNE), que lhes concedeu aparato para produzirem os panfletos que foram atirados por sobre os muros da empresa, na tentativa de conscientizar os companheiros para uma revolução socialista. Esses eventos, articulados, forneceram elementos para que o regime construísse a imagem de criminosos que foi atribuída durante anos aos participantes da greve e justificasse a vigilância e a violência contra eles e suas famílias.

No entanto, um dos acontecimentos mais significativos da narrativa coletiva foi quando José Campos Barreto (naquele momento já membro da Vanguarda Popular Revolucionária) ameaçou explodir uma caldeira com um revólver em mãos e fez um discurso convocando todos os soldados que os cercavam a se juntarem aos trabalhadores contra o governo. Esse ato foi o que, principalmente, dividiu as opiniões dos entrevistados, que consideraram seu radicalismo necessário ou prejudicial ao movimento, e ao mesmo tempo símbolo de coragem e insubmissão, o que custou a sua prisão e tortura e o transformou num dos heróis da coletividade.

Esse conjunto de eventos lembrados por eles provocou o cerco à cidade de Osasco, tomada por brucutus e soldados da Força Pública, que realizaram várias prisões de metalúrgicos, dentre eles José Groff, presidente da Comissão de Fábrica, e José Campos Barreto que, segundo os membros da FNT, havia exagerado ao ameaçar explodir a caldeira. Outros trabalhadores fugiram, como Inácio Gurgel, Roque Aparecido e João Joaquim, tendo os dois últimos refugiado-se na igreja matriz de Santo Antônio, buscando proteção dos padres. José Ibrahin, presidente do Sindicato dos Metalúrgicos de Osasco, permaneceu na clandestinidade. Por fim, entre julho de 1968 e setembro de 1969, todos acabaram demitidos e/ou presos em emboscadas organizadas pela repressão. ${ }^{23}$

Os relatos revelaram que a crença na inevitabilidade da vitória não contava com o imprevisto da repressão. A forma como a ditadura agiu e também a

23 Sobre os detalhes da greve, ver COUTO, Marcelo. Greve na Cobrasma: uma história de luta e resistência. São Paulo: Annablume, 2003; ROVAI. Osasco 1968; WEFFORT, Francisco. Participação e conflito social: Contagem e Osasco: 1968. Cadernos CEBRAP, n 5, São Paulo, 1972. 
descoberta de que eles não controlavam o rumo dos acontecimentos frustrou seus intentos e levou a greve ao seu fim, ainda que Antônio Roberto Espinosa, junto a outros companheiros, tentasse manter o que chamaram de "grevilha". Em pontos próximos à fábrica, eles distribuíam panfletos conclamando os colegas a permanecerem firmes na manutenção da paralisação, mesmo que fosse necessária uma ação mais violenta.

Os narradores que foram membros da Frente Nacional do Trabalho apontaram como motivo para o rápido desmantelamento da greve a radicalização de seus companheiros, resultado da excessiva politização do movimento, devido às relações com os intelectuais, a União Nacional dos Estudantes e os grupos armados, o que os teria desviado de suas "verdadeiras intenções". Para eles, os estudantes nada conheciam sobre a vida dura na fábrica e teriam pouco a contribuir com o movimento. Além disso, o fato de o Grupo Osasco decidir pela antecipação da paralisação que deveria ocorrer só em outubro, junto com outros sindicatos, teria isolado os osasquenses e decretado a sua derrota. Para os operáriosestudantes, no entanto, foi o conservadorismo de alguns setores católicos o que teria enfraquecido o conjunto de grevistas, impedindo o fortalecimento da união entre operários e setores revolucionários da sociedade.

A repressão que se abateu sobre Osasco, a partir de julho de 1968, provocou uma brutal mudança de rumo na vida dos operários e também de suas famílias. Essa passagem dolorosa mostrou-se, nas narrativas, um momento decisivo na vida dos envolvidos; funcionou como fratura, ferida que marcou corpos e espíritos dos grevistas e de toda a rede afetiva que os circundava. Uma conexão de arbitrariedades e medo transformou as vidas dos que até então tinham atuado para reivindicar salários e melhores condições de trabalho, os ligados à FNT, ou para derrubar a ditadura, como o Grupo de Osasco. O tratamento dado aos seus parentes, na tentativa dos militares de encontrá-los e prendê-los, não foi menos violento do que a ação nas indústrias.

As memórias femininas - das esposas e irmãs desses trabalhadores - fizeram menção aos momentos de angústia vivenciados por elas e seus parentes, enquanto tinham suas casas vigiadas, invadidas e reviradas, à procura de "provas" contra eles. Algumas mulheres chegaram a ser presas e torturadas, e também a fugir, tomadas pelo pavor de verem seus filhos sequestrados. O papel delas como "negociadoras" nas delegacias, assim como articuladoras da família e da vizinhança, na realização de abaixo-assinados pela soltura dos presos, ou na arrecadação de comida e dinheiro para ajudar os desempregados, foi fundamental em todo o processo de resistência operária. Muitas delas chegaram a esconder pessoas, queimar documentos e levar recados escondidos em suas roupas, mantendo o contato entre prisioneiros e familiares, histórias ainda ignoradas pela sociedade e pouco exploradas pela historiografia brasileira. ${ }^{24}$

Os diferentes mecanismos de fuga para escapar da repressão e das prisões foram abordados nas narrativas dos homens: pular cercas, esconder-se na igreja, vestir-se de mulher, passar-se por outras pessoas, mentir diante dos policiais sobre sua identidade. Enfim, enganar as autoridades policiais e militares tornou-se uma tática construída na improvisação, muitas vezes sem sucesso, contra as estratégias de controle e vigilância.

Como afirmou Michel de Certeau, a arma dos fracos estaria na capacidade de perceber o momento do golpe, na luta contra o tempo e o espaço vigiado pelo

24 Sobre suas memórias e histórias ver ROVAI. Osasco 1968. 
inimigo. ${ }^{25}$ Foi exatamente isso que os relatos revelaram, reafirmando o caráter épico do enfrentamento coletivo à ditadura, mesmo que momentaneamente. As histórias de subterfúgios compartilhadas pelos entrevistados, citadas por um e outro como consentimento e fortalecimento da experiência em comum, tiveram caráter desafiador e ousado. Não trataram apenas da dor, mas do misto de improvisação e de lealdade aos seus companheiros em meio ao clima de desespero que tiveram que enfrentar: inventaram "pontos" e "aparelhos" para ganhar tempo, salvar vidas e poupar si mesmos das sevícias constantes.

Mesmo aqueles que conseguiram voltar para a fábrica, depois de permanecerem foragidos, escondidos ou presos por algumas horas ou dias, não demoraram a descobrir que o movimento de 1968 teria um preço alto a ser pago. A greve de Osasco foi considerada um ato subversivo e o crime foi registrado em suas carteiras de trabalho, impedindo que pudessem ter um novo emprego. Estigmatizados como subversivos, aqueles que não foram para a clandestinidade e a guerrilha, conheceram outro tipo de isolamento, interpretado também como punição e destruição de suas vidas: o desemprego. Inácio Gurgel, José Groff e João Cândido ficaram desempregados e sofreram com a recusa de oportunidades; os que conseguiram retornar ao trabalho foram constantemente vigiados, num clima de desconfiança e medo, o que foi definido por alguns deles como uma forma de exílio. Segundo Inácio Gurgel, foi "como morrer a cada dia”.

O Grupo Osasco assumiu de vez a opção pela luta armada, a partir do segundo semestre de 1968, distanciando-se dos companheiros que retornaram à fábrica e às igrejas. Para seus membros, a greve fazia parte do projeto e da organização de um plano revolucionário. Mesmo que fracassada, a experiência serviu para preparar aqueles que ingressaram nos grupos armados e iniciaram nova etapa na resistência ao regime.

A clandestinidade e a guerrilha representaram para José Ibrahin, José Campos Barreto, Antônio Roberto Espinosa e Roque Aparecido da Silva, o novo e único caminho possível a ser trilhado no combate à ditadura. Os entrevistados forneceram os motivos que os levaram ao ingresso definitivo na luta armada: a continuidade do projeto político ligado à greve, a crescente repressão, o fim da possibilidade de negociação, a opção pela clandestinidade tentando evitar a prisão. O Ato Institucional $n^{\circ} 5$, de 13 de dezembro de 1968, levou-os a intensificar ainda mais a crença na radicalização, pois a ideia de revolução colocava-se como possibilidade próxima e evidente.

O mergulho na luta armada foi apresentado por eles como caminho sem volta, sinal do esgotamento da resistência em outros moldes, já que o regime teria fechado todos os canais de diálogo e de manifestações. Ainda mais: colocaram-se como agentes de forças determinadas pela "grande História", transformados de tal forma que a possibilidade de recuo era impossível. O que para os trabalhadores da FNT seria a razão do fracasso da luta dentro da fábrica e o possível desvio da greve, para os que optaram pela guerrilha era o inevitável e o irrecusável. Suas atitudes não teriam sido exatamente escolhas, mas destinos: "é como se você estivesse amaldiçoado!", afirmou em entrevista José Ibrahin.

O Al-5 foi lembrado por esses trabalhadores como "o corte em suas vidas", dado ao caráter endurecedor e permanente que o governo atingiu, com seus núcleos de tortura e um aparato repressivo cada vez mais especializado em extrair pela

25 CERTEAU, Michel. A invenção do cotidiano. Petrópolis: Vozes, 1998. 
dor as informações que procuravam. A censura aos jornais e a propaganda contra os chamados subversivos, principalmente por meio de cartazes de "procurados", amedrontavam a população e estimulavam delatores em várias instâncias socais. Sobre Osasco, assim como em muitas cidades operárias, construiu-se grande desqualificação, desarticulação e medo, transformando-a em "cidade do crime".

Os entrevistados lembraram a truculenta campanha contra os osasquenses como forma de combate proporcionada pelo regime contra os trabalhadores, fossem eles comunistas ou cristãos. Houve grande ressentimento nas narrativas com relação às representações bizarras nas primeiras páginas de jornais, como o Notícias Populares, mostrando constantemente notícias de assassinatos, "bodes estupradores" e de "bebês-diabos". ${ }^{26}$ Para os narradores, iniciou-se um trabalho de despersonalização e de isolamento, jogando para o esquecimento a vanguarda e o protagonismo deles no cenário nacional. O regime civil-militar tentou definir o que deveria ser guardado na memória e o que deveria ser esquecido, num plano racional de "saneamento ideológico da direita".

A despersonalização de Osasco foi entendida como estratégia do regime para ofender e fazer ruir o que eles haviam construído. Para fazer calar, criando clima de vergonha, desconfiança e delação, o que jogou parte das pessoas na clandestinidade e reforçou a luta armada. A imagem da cidade produzida pelas campanhas e pelos jornais tentou convencer, pela repetição, que ela era uma ameaça contra a nação. Para os trabalhadores, o Estado tratou de construir um "outro social”, perigoso, desmoralizado, com o qual não se identificaram jamais.

Por outro lado, a vergonha gerada na população de Osasco com o intuito de formar o sentimento de culpa ou o medo devido à confusão entre crime político e "comum" colaborou para produzir o "silenciamento" da experiência vivida ou assistida em julho de 1968. Não se pode esquecer que na década de 1970 começava a agir o grupo "justiceiro" comandado pelo delegado Sérgio Fernando Paranhos Fleury, conhecido como "Esquadrão da Morte”. Sua atuação na periferia, assassinando indiscriminadamente todos aqueles que considerasse ou apontasse como perigosos acentuava ainda mais o clima de terror, assim como a aversão à imagem da cidade, inscrita na onda difamante contra os grupos armados. ${ }^{27}$

O incômodo, confundido com a culpa coletiva, deveria contribuir - e contribuiu - para a obstrução de outras versões favoráveis aos operários e a outros sujeitos na luta contra a ditadura civil-militar e sua violência. Tornou-se "silenciamento".

As narrativas, no entanto, demonstraram o inconformismo operário diante da "arapuca" ideológica armada pelo regime militar para acuá-los e desorganizá-los. Os entrevistados acusaram a ditadura de provocar sentimentos - vergonha e culpa - que não fizeram parte de suas trajetórias de vida. Para senti-los, os trabalhadores teriam que avaliar suas ações comparadas a um referencial moral considerado correto, um tipo de patriota ou de cidadão que lhes fizesse renegar o que fizeram ou foram. Cientes da perversidade da máquina ditatorial recusaram-se a aceitar os estereótipos e fizeram de seus testemunhos uma forma de denúncia no presente.

26 Os fatos do jornal Notícias Populares, os programas de televisão da Rede Globo, as piadas no programa Sílvio Santos, além de tantas outras ouvidas nas ruas pelos moradores osasquenses, foram estratégias de desqualificação criadas nos anos 1970. Maria Lourdes Motter realizou pesquisa mostrando como os jornais O Estado de São Paulo, Folha de São Paulo e Folha da Tarde abordaram a greve de Osasco e a guerrilha. Sobre isso, sugiro a leitura de seu livro, MOTTER. Ficção e História: imprensa e construção da realidade. São Paulo: Arte e Ciência, 2001.

27 Sobre o tema ver SOUZA, Percival. Autopsia do medo: vida e morte do delegado Sérgio Paranhos Fleury. São Paulo: Editora Globo, 2000; BICUDO, Hélio P. Meu depoimento sobre o esquadrão da morte. São Paulo: Martins Fontes, 2002. 
É importante lembrar que a propaganda contra Osasco foi fruto de um projeto mais amplo, já que a cidade não estava isolada e não era a única a resistir à ditadura. As imagens criminosas eram parte da campanha promovida pelo governo contra a atuação dos militantes tratados como terroristas, em todo o território. Como subversivos perigosos, Roque Aparecido e José Ibrahin foram presos juntos, em 1969, após a descoberta do "aparelho" em que estavam. Junto com eles estava Ana Maria Gomes, uma operária da empresa Osram, também de Osasco, e que ingressou na VPR junto com o irmão, Osny Gomes. ${ }^{28}$

Nas lembranças dos militantes do Grupo Osasco, que passaram momentos presos no Deops e/ou no Presídio Tiradentes, muitas feridas se revelaram, muitos traumas, não apenas provocados pela tortura física, mas também psicológica. Ibrahin falou sobre os momentos de angústia e do desejo "libertador" do suicídio diante da humilhação, da perda de controle sobre o corpo e a mente e da possibilidade de trair companheiros, entregando nomes e lugares. Antônio Roberto Espinosa se referiu ao barulho terrível das chaves das celas, nas mãos dos perpetradores, indicando que alguém seria levado a qualquer momento para ser seviciado. Roque Aparecido lembrou a tristeza pelas perdas de entes queridos assassinados pelos órgãos da repressão; em especial, de seu irmão, João Domingues, também militante da VPR, que não suportou as barbaridades cometidas contra ele no cárcere. ${ }^{29}$

José Ibrahin e Roque Aparecido acabaram sendo trocados por embaixadores sequestrados em ações conjuntas de grupos armados, que exigiam a libertação dos presos políticos: o primeiro estava na lista dos 15 que saíram do país no avião Hércules, em troca da libertação do estadunidense Charles Burke Elbrik, em setembro de 1969; o segundo conseguiu sair da prisão entre os 70 banidos que foram o "pagamento" exigido pela VPR para a soltura do embaixador suíço, Giovanni Bucher, em 1970. Ambos enfatizaram os sentimentos de ansiedade e solidão no exílio e de agradecimento à recepção e aos laços solidários em países como Cuba, Chile, Argélia, França e Suécia, o que contribuiu para que sobrevivessem.

Assim, mais do que a greve e o confronto com o regime civil-militar em 1968, as consequências existenciais e emocionais sobre os trabalhadores osasquenses e seus entes queridos transformaram o evento aparentemente breve numa intensa e longa experiência, cujo significado se estendeu na memória e provocou uma ferida, individual e coletiva, ainda não curada. ${ }^{30}$ Daí a importância em contar, compartilhar com a sociedade um passado traumático, que atingiu toda a coletividade, senão como fato, mas como possibilidade.

28 Ana Maria Gomes e Roque Aparecido namoravam e se casaram para atuar de forma insuspeita na vizinhança. Ela não foi a única mulher osasquense participante da greve ou a ingressar na luta armada, mas há poucos dados e estudos sobre isso. No dia da greve, cerca de 200 trabalhadoras de uma fábrica de fósforo se dirigiram à Cobrasma em apoio aos operários, mas foram enviadas de volta por eles.

29 João Domingues da Silva era açougueiro e acompanhou seu irmão, Roque, na luta armada. Participou, em 1969, do assalto ao cofre do governador Ademar de Barros, em São Paulo, numa ação de membros da VPR. Ao tentar fugir, acabou ferido e foi preso na casa de sua irmã, Iracema dos Santos, em Osasco. Foi barbaramente torturado até a morte, aos 18 anos de idade.

30 De acordo com Selingmann-Silva, "trauma" deriva de uma raiz indo-europeia com dois sentidos: 'friccionar, triturar, perfurar'; mas também 'suplantar', 'passar através'. Nesta contradição - uma coisa que tritura, perfura, mas que, ao mesmo tempo, é o que nos faz suplantá-la, já se revela, mais uma vez, o paradoxo da experiência catastrófica. A possibilidade de narrar o trauma permite a possibilidade de superá-lo e renascer. NESTROVSKI \& SELINGMANN-SILVA. Catástrofe e representação. São Paulo: Escuta, 2000, p. 8. 


\section{Contar e aconselhar}

Quando perguntados sobre a importância de falar de suas experiências e do significado de sua luta, os trabalhadores demonstraram convergência de sentidos em suas interpretações. Os colaboradores buscaram atenção para seus feitos, enquanto coletividade, contra circunstâncias entendidas como injustas; renderam homenagens às pessoas com as quais partilharam seus sentimentos e expectativas; elaboraram críticas e avaliaram o ônus da experiência. Para isso, trataram-se como grupo, chamaram-se de "nós". Mesmo quando a fala era pessoal, abordaram vivências e sentimentos em comum, lembrados conjuntamente; evocados e discutidos anteriormente em outros espaços e momentos.

O ato de recordar não foi solitário, mesmo que seus companheiros estivessem ausentes fisicamente, pois as referências se ancoravam em fatos vivenciados conjuntamente, de forma a dar sentido e legitimação ao que contavam. Complementaram, dialogaram, concordaram, divergiram, desaprovando, pedindo apoio ou comprovação nas lembranças de outros quanto aos nomes, lugares, eventos jocosos ou traumáticos. Mostraram que a memória coletiva mantém-se viva e presente na articulação, nos acordos e no reconhecimento; nas discordâncias e insinuações, sustentando a noção de que viveram e contaram juntos.

Para os trabalhadores de Osasco, tomar a palavra, no contexto da reflexão sobre a redemocratização, configurou-se como ato político e ético. Recordar a greve e a luta que se estendeu contra o regime civil-militar significou tomar posição moral e identitária diante do "silenciamento" proporcionado não apenas pelo autoritarismo, durante os vinte anos de regime de exceção, mas também pela Anistia, em 1979, que instituiu um perdão oficial a todos os seus algozes, procurando calar aqueles que exigiam o julgamento e a punição dos que violaram os direitos humanos, assim como a reparação para as vítimas. Um aspecto marcante das narrativas foi a cobrança de uma releitura dos crimes cometidos pelos agentes do Estado e que, segundo os entrevistados, teriam sido jogados ao esquecimento, condenando toda a sociedade ao silêncio. Para eles, haveria ainda uma história a ser contada e continuada, que seria aquela que lhes permitisse ver o processo de redemocratização efetivado mediante o conhecimento do passado pela sociedade e a realização da justiça.

Os entrevistados, no momento em que testemunharam suas experiências, mostraram ainda lutar contra os estereótipos construídos em torno da cidade de Osasco e que buscaram marcar suas subjetividades de forma negativa. $O$ momento atual é aquele em que podem manifestar suas lembranças e dizer quem eles foram e são, ou quem gostariam de ser, contra todo tipo de discurso desqualificador. O fato de terem sido jovens ou de terem sido fundadores de uma nova condução dos trabalhadores na fábrica, de pertencerem a grupos armados ou a uma nova Igreja voltada aos pobres, tornou consenso a ideia de que algo grandioso foi inaugurado por suas ações durante a greve de Osasco, em 1968. Tendo eles pertencido ao Grupo de Osasco ou à FNT, não se apresentaram como nem se sentiram meros objetos das autoridades e de líderes, mas senhores de suas escolhas, o que exigiu deles certo sacrifício. A maior parte de suas falas atribuiu à greve de Osasco importância histórica, considerando que o que fizeram tornou-se conhecido, admirado e rememorado em todo o mundo, comparado a eventos como o Maio Francês, em 1968, ou à organização dos trabalhadores na Rússia. Foram eles os criadores da "primeira comissão de fábrica" e do primeiro 
“sindicato, que uniu operários e estudantes". Atribuíram às suas ações um caráter inaugural e épico.

O medo, sentimento mais íntimo e entendido muitas vezes como motivo para vergonha, foi considerado pelos operários como uma condição para sua coragem e resistência. Sentimento humano que lhes fragilizou e lhes engrandeceu ao mesmo tempo, seja como atitude própria dos revolucionários ou como calvário comparado ao de Cristo, fruto da fé em um mundo possível, mais justo. Assumir o temor não significou aceitar a condição de submissão ao regime, nem de traição aos companheiros. Não teve sentido de fragilidade ou recuo, mas sua expressão pode ser entendida como uma concessão que os entrevistados fizeram a uma memória pouco verbalizada pelo mundo masculino, normalmente relacionado a um imaginário de virilidade.

Com olhos e alma no presente, todos eles reportaram-se à comunidade moral ou afetiva para ancorar os eventos escolhidos pela memória individual. A ligação coletiva parece ter sido fundamental para a sobrevivência de cada um diante das dificuldades que nasceram da greve e da violência perpetrada pelo regime autoritário. $O$ sentimento de pertencimento ao grupo lhes permitiu resistir aos elementos desestruturantes da perseguição posterior à greve: o desemprego, a clandestinidade, a prisão, o medo, a tortura e o exílio, e lhes permitiu construir uma memória orgulhosa.

A greve de Osasco deixou heranças, segundo eles, como as greves realizadas pelos metalúrgicos do $A B C$ entre 1978 e 1980 . O que viveram em 1968 serviu como inspiração e exemplo para os trabalhadores que construíram novas estratégias de enfrentamento à ditadura, mais tarde. Foi consenso narrativo a ideia de que os avanços conquistados em relação aos direitos trabalhistas e a força acumulada pela maior parte dos sindicatos brasileiros nos últimos anos devem-se à luta empreendida por eles na década de 1960.

Em conjunto, os narradores se apresentaram como críticos da nova forma de sindicalismo, definida como "vendida aos empresários e ao capitalismo", "submissa em plena democracia", "acomodada" e "de aluguel”, como afirmou, dentre eles, José Groff. Para eles, seu papel como agentes da história não parou no tempo, pois o passado permanece ainda em aberto, como algo que não findou e que precisa ser melhor conhecido para que a justiça seja feita, realizando os sonhos que ainda não findaram. Colocaram-se como pessoas que ainda podem colaborar com os movimentos sociais, revelando-se cidadãos ativos na atualidade. Foi com essa expectativa - de um presente redentor do passado - que a maioria das entrevistas dos trabalhadores de Osasco se encerrou.

\section{Considerações finais}

Entendo que o trabalho com histórias orais de operários tenha contribuído para elucidar fatos relativos à greve de Osasco em 1968, como outras pesquisas já o fizeram; mas o maior mérito em se trabalhar com a memória é perceber que os sentimentos, projetos e crenças demonstrados nas narrativas colaboraram para que os sujeitos construíssem a si mesmos, partilhando e ressignificando o passado, ao mesmo tempo dando sentido às suas vidas no presente e forjando sua identidade coletiva. Mais do que isso, lidar com testemunhos traumáticos e contribuir para a sua publicização pode permitir que, ao tomar conhecimento de 
experiências sob o regime autoritário, a sociedade brasileira compreenda que a violência cometida naqueles tempos sombrios pode representar a possibilidade de violação contra a dignidade de qualquer indivíduo.

Ao falarem sobre suas vidas, os metalúrgicos que participaram da greve de Osasco em 1968, buscaram narrar e explicar os caminhos percorridos e contribuir para o debate que hoje se estabelece no país sobre "o direito à memória, à verdade e à justiça". As narrativas são processo de recontar contínuo, significam a luta contra a dissolução e a fragmentação do tempo diluidor de memórias. Lembrar a posição de resistência diante das tentativas de desumanização representou um processo terapêutico, enfrentamento do trauma, transpondo suas dores, o que Sigmund Freud chamou de translaboração.

Testemunhar pode ter sentido de caminhar, projetar o futuro, reforçando a ideia de que o que a comunidade construiu valeu a pena e deixou frutos. Se os trabalhadores osasquenses chegaram a ser ofendidos, presos, torturados e transformados em bandidos numa "cidade do crime" - por meio de discursos e de práticas autoritárias e violentas -, contar sobre esse processo pode representar o momento de revidar e passar a história a limpo, lutando contra o preconceito em oposição a uma memória oficial que durante anos os condenou ao esquecimento.

Recebido em: 20/02/2014

Aprovado em: 20/04/2014 